\title{
Feeding interactions between planktonic copepods and red-tide flagellates from Japanese coastal waters
}

\author{
Shin-ichi Uye, Kazuhiro Takamatsu \\ Faculty of Applied Biological Science, Hiroshima University, Saijo-cho, Higashi-Hiroshima 724, Japan
}

\begin{abstract}
Feeding interactions between inshore marine copepods Pseudodiaptomus marinus and Acartia omorii, and 15 red-tide flagellates were studied by examining egestion rate, mortality and egg production rate of the copepods offered a suspension of each phytoplankton species. Among several species of poor quality as food, Olisthodiscus luteus (Raphidophyceae) was nearly completely rejected by $P$. marinus, and Gymnodinium nagasakiense (Dinophyceae). Heterosigma akashiwo (Raphidophyceae, Nagasaki University strain), Chattonella marina (Raphidophyceae) and Fibrocapsa japonica (Raphidophyceae) were almost entirely rejected by $A$. omorii. Since these flagellates are of preferred cell size and have no hard undigestible cell walls, the rejective feeding by copepods was suspected to be chemically mediated. Effects of chemical stimuli from O. luteus (to P. marinus) and G. nagasakiense (to A. omorii) were examined in detail by conducting comparative feeding experiments in a suspension of Heterocapsa triquetra (Dinophyceae), a normally edible species. Addition of filtrate from the cellhomogenate of exponentially growing O. luteus or G. nagasakiense to the suspension reduced copepod filtering rate on $H$. triquetra, indicating deterrent chemical compounds are intracellularly present These compounds were ephemeral, being deactivated within $12 \mathrm{~h}$ at $20^{\circ} \mathrm{C}$. Chemically-mediated rejection by copepods is an important factor in the development of monospecific red tides.
\end{abstract}

\section{INTRODUCTION}

A considerable amount of data has been compiled on feeding behavior of copepods, since they are the major constituents of herbivorous zooplankton. Suspensionfeeding copepods were thought to be passive or mechanical feeders: their particle selection was sizedependent based on the morphology of the filtering mesh of the second maxillae (Boyd 1976, Nival \& Nival 1976. Frost 1977). However, recent studies show copepods are discriminating feeders. Donaghay \& Small (1979) reported that a copepod, Acartia clausi, selected phytoplankton cells over plastic beads of similar size and equal availability. Poulet \& Marsot (1978) first demonstrated chemically-mediated selective feeding of copepods, which ingested microcapsules enriched with phytoplankton homogenate at much higher rates than those without enrichment. The importance of chemical properties of particles was suggested by Friedman \& Strickler (1975) who found chemoreceptorlike organs in copepod feeding appendages. Using high-speed cinematography, Alcaraz et al. (1980) and Koehl \& Strickler (1981) showed real selection behavior of copepods: they captured, handled (probably tasted) and ingested (or rejected) particles according to their quality.

Probably for similar chemical reasons, several bloomforming flagellate species are rejected or fed upon at lower rates by copepods. Tomas \& Deason (1981) reported Olisthodiscus luteus (this is suspected to be Heterosigma akashiwo; Hara et al. 1985, Hara \& Chihara 1987) which chronically forms red tides in Narragansett Bay, Rhode Island, USA, was rejected by Acartia hudsonica and A. tonsa. Huntley (1982) also found that Gymnodinium flavum, a causative species of red tides in the waters off La Jolla, California, USA, was ingested at extremely low rates by Calanus pacificus. Recent studies (Turner \& Anderson 1983, Huntley et al. 1986, Van Alstyne 1986, Gill \& Harris 1987, Ives 1987. Sykes \& Huntley 1987) show further rejected species, including Gonyaulax tamarensis, Gyrodinium aureolum, Protoceratium reticulatum (= Gonyaulax grindleyi), Ptychodiscus brevis and Scrippsiella trochoidea.

Growth of phytoplankton populations in the field is controlled not only by various environmental factors 
(e.g. temperature, salinity, light intensity, nutrients, growth-promoting substances, water turbulence, etc.), but also by zooplankton grazing pressure (Steele 1974 , Frost 1980). The importance of zooplankton grazing pressure has been demonstrated in the course of development to red tides (Turner \& Anderson 1983, Watras et al. 1985, Uye 1986). If bloom-causing phytoplankton species have adapted to employ chemical defences against being grazed (Huntley et al. 1986), the effect of zooplankton grazing pressure will be unimportant. There are 62 bloom-forming phytoplankton species in Japanese coastal waters including species causing mass kills of finfish and shellfish (Nishio 1982, Okaichi 1987), but none of these species have been examined to determine whether they might be rejected by planktonic copepods.

In this study, we offered 15 red-tide flagellates, which had been originally isolated from Japanese coastal waters, to 2 inshore marine copepods, Pseudodiaptomus marinus and Acartia omorii, in order to examine their feeding interaction. We found that a dinoflagellate (Gymnodinium nagasakiense) and 4 raphidophycean species (Olisthodiscus luteus, Heterosigma akashiwo [NU], Chattonella marina and Fibrocapsa japonica) were rejected by copepods. The effects of grazing pressure by zooplankton in the course of development to red tides are discussed.

\section{MATERIALS AND METHODS}

Phytoplankton. Fifteen species of phytoplankton $(8$ species of Dinophyceae, 4 species - one of them represented by 2 different strains - of Raphidophyceae, 2 species of Prasinophyceae and 1 species of Euglenophyceae) were obtained from the culture collections of Nagasaki University or the National Institute of Environmental Studies (Table 1). They ranged in maximum cell width from 12.5 to $90 \mu \mathrm{m}$ (Table 1 ), a preferred particle size range for suspension-feeding copepods (Richman et al. 1977, Uye \& Kasahara 1983). Phytoplankton were cultured in $\mathrm{f} / 2$ medium (Guillard \& Ryther 1962$)$ at $20^{\circ} \mathrm{C}\left( \pm 1^{\circ} \mathrm{C}\right)$ under a $12-12 \mathrm{~h}$ lightdark cycle. Only cells in the logarithmic phase of growth were suspended in glassfiber (Whatman GF/C) filtered seawater and offered as food for copepods. The egestion rate, survivorship and egg production rate of copepods were examined under bloom conditions, with concentrations ranging from $2 \times 10^{3}$ to $2 \times 10^{4}$ cells $\mathrm{ml}^{-1}$. Although concentrations for each diet were not equivalent, each diet was presented in excess, with carbon concentration (calculated from Mullin et al. 1966) ranging from 600 to $2400 \mu \mathrm{g} \mathrm{I}^{-1}$.

Copepods. Zooplankton samples were collected by a $0.45 \mathrm{~m}$ plankton net (200 $\mathrm{m}$ mesh opening) with 11 volume cod-end in Fukuyama Harbor, Hiroshima Pre-

Table 1 . Species of red-tide flagellates used and their source and size

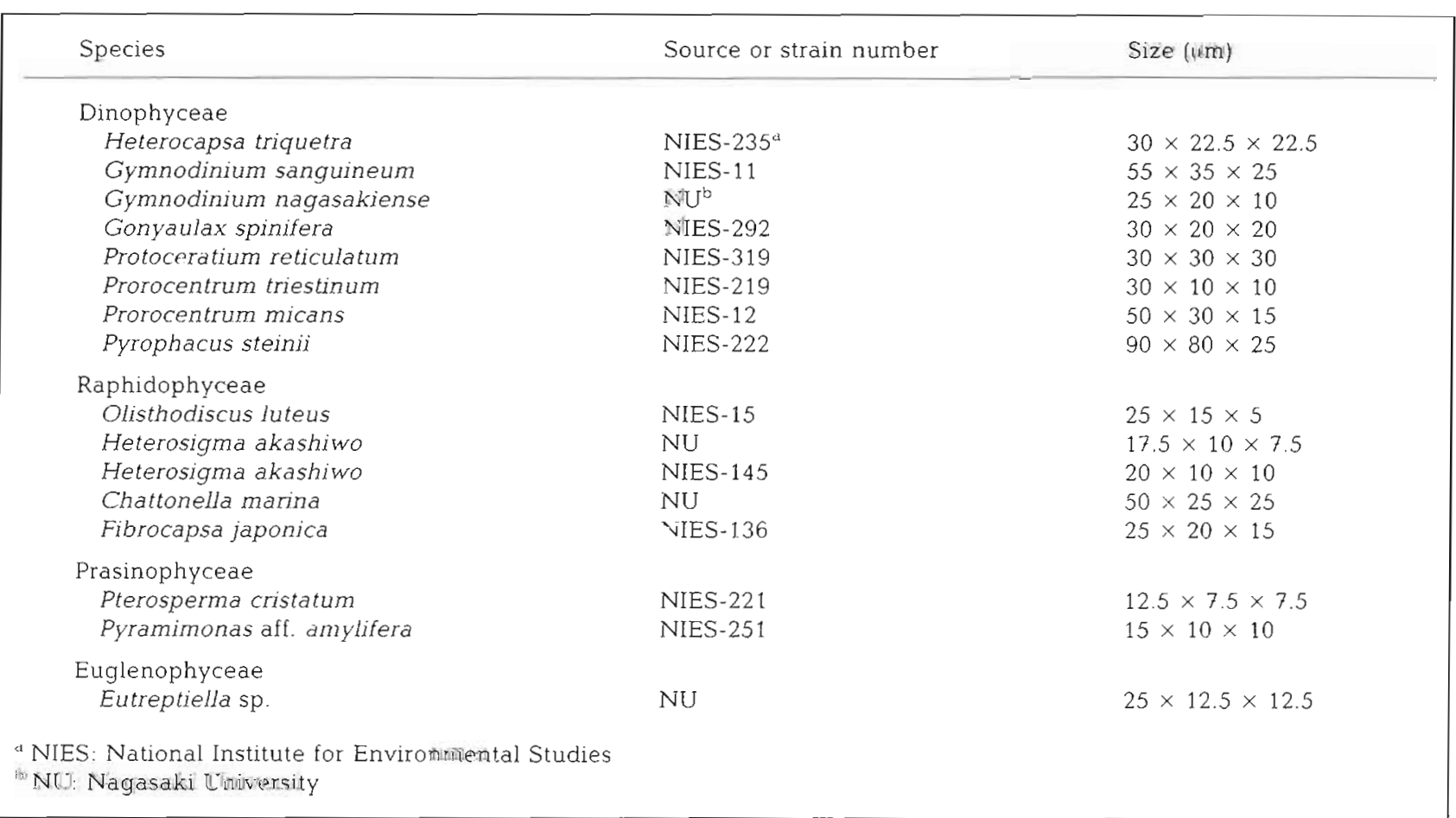


fecture, Japan, and brought back to our laboratory within $30 \mathrm{~min}$. Adult females of 2 copepod species, Pseudodiaptomus marinus (collected mainly in early summer and fall 1986 and 1987) and Acartia omorii (collected in fall 1986 and 1987 and spring 1987), were sorted from the plankton samples and used as grazers. These copepods were starved for $24 \mathrm{~h}$ in glassfiberfiltered seawater before each experiment. Subsequent experiments were conducted at $20^{\circ} \mathrm{C}$ and under a 12 $12 \mathrm{~h}$ light-dark cycle, unless otherwise noted.

Egestion rate. Copepods were individually transferred into test tubes containing $30 \mathrm{ml}$ of a suspension and incubated for $24 \mathrm{~h}$. Five to 10 tubes were prepared for each phytoplankton species. At the end of the experiment, survival of copepods was checked and fecal pellets deposited on the bottom of tubes were pipetted into a counting tray. Pellets were counted and their length and width measured for up to 10 randomly selected pellets. When fecal pellets were broken, the ends of pellets were counted, and half of this number was assumed to be the number of intact pellets.

Mortality. Fifty copepods were transferred into each beaker containing $500 \mathrm{ml}$ of a suspension and reared for $20 \mathrm{~d}$ for Pseudodiaptomus marinus and $15 \mathrm{~d}$ for Acartia omorii. The same number of copepods were also kept in beakers containing only filtered seawater. Dead individuals were counted and removed daily. At the same time, fecal pellets on the bottom of the beakers were pipetted out, and about a quarter of the

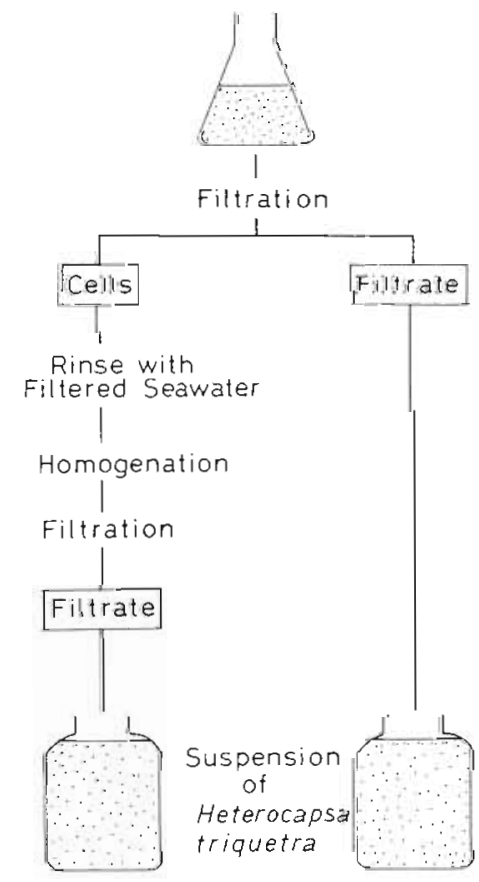

Fig. 1 Schematic presentation for the preparation of filtrate from culture and filtrate from cell homogenate of Olisthodiscus luteus or Gymnodinium nagasakiense content was replaced by newly prepared medium or filtered seawater.

Egg production. A preliminary experiment revealed that egg sac production by Pseudodiaptomus marinus ceased after $4 \mathrm{~d}$ starvation. Hence, $P$. marinus were first kept in filtered seawater for $4 \mathrm{~d}$ to expend their stored energy and then 10 copepods were transferred into a beaker containing $500 \mathrm{ml}$ of a suspension. Production of a new egg sac was monitored for $7 \mathrm{~d}$.

A preliminary experiment indicated that spawning of Acartia omorii ceased after $3 \mathrm{~d}$ starvation but recovered to the previous level after $3 \mathrm{~d}$ of feeding on normally edible phytoplankton. Hence, $A$. omorii were first starved for $3 \mathrm{~d}$, fed with respective phytoplankton species for $3 \mathrm{~d}$, and then individually incubated in each test tube containing $30 \mathrm{ml}$ of a suspension. Eggs produced over $24 \mathrm{~h}$ were counted.

Chemical compounds which inhibit copepod feeding. The experiments mentioned above (see 'Results') revealed that Olisthodiscus luteus was almost completely rejected by Pseudodiaptomus marinus and Gymnodinium nagasakiense was one of 4 species rejected by Acartia omorii, while Heterocapsa triquetra was a preferable phytoplankton for both copepod species. Since differences in shape, cell size and cell wall hardness did not explain the difference in food value, we suspected the rejective feeding was chemically mediated, as reported by Huntley et al. (1986) and Van Alstyne (1986).

In order to elucidate the origin of the inhibitory compounds, whether intracellular or extracellular, feeding experiments were conducted following the procedures shown in Fig. 1. A culture of Olisthodiscus luteus or Gymnodinium nagasakiense was filtered through glassfiber filters to separate filtrate and cells. Cells on a filter were rinsed with ca $50 \mathrm{ml}$ of filtered seawater, transferred to a homogenation tube which was externally cooled with ice, and homogenized in 5 to $10 \mathrm{ml}$ of filtered seawater. This homogenate was filtered through a glassfiber filter to obtain the filtrate of cell homogenate. Either the filtrate of culture or the filtrate of cell homogenate was sufficiently diluted on a suspension of Heterocapsa triquetra, which had been placed in a dark room for $24 \mathrm{~h}$ to prevent its growth, to contain the algal compounds derived from ca 2000 cells per $\mathrm{ml}$ of the suspension. Bottles containing a suspension of only $H$. triquetra were also prepared. Twenty Pseudodiaptomus marinus or 10 Acartia omorii were transferred to each grazing bottle $(450 \mathrm{ml}$ for $P$. marinus, $250 \mathrm{ml}$ for $A$ omorii). Four experimental bottles and 2 control bottles (containing no copepods) were prepared at each cell concentration. These bottles were placed on a grazing wheel $(1 \mathrm{rpm})$ for $6 \mathrm{~h}$ in darkness. The concentration of $H$. triquetra cells before and after the experiment was determined with a Coulter Counter 
(Model ZB). Filtering rate of copepods was calculated after Frost (1972).

To test heat resistance of the inhibitory compounds, the filtrate of cell homogenate was heated at 40,60 and $80^{\circ} \mathrm{C}$ (but only $80^{\circ} \mathrm{C}$ for Gymnodinium nagasakiense) for $10 \mathrm{~min}$, cooled to $20^{\circ} \mathrm{C}$ and added to a suspension of Heterocapsa triquetra. Grazing experiments were conducted as above. Durability of the inhibitory effect was also tested by adding the filtrate of cell homogenate which had been kept at $20^{\circ} \mathrm{C}$ for $2,3,4,6,12$ and $24 \mathrm{~h}$ (but only for 12 and $24 \mathrm{~h}$ in the case of $G$. nagasakiense) before grazing experiments.

\section{RESULTS}

\section{Egestion rate}

Pseudodiaptomus marinus and Acartia omorii produced cylindrical fecal pellets with mean lengths of 196 and $144 \mu \mathrm{m}$ and mean widths of 35 and $38 \mu \mathrm{m}$, respectively. The number and size of fecal pellets varied depending on the phytoplankton species provided as food. Hence, egestion rates of copepods, in terms of the volume of fecal pellets produced per individual per day, differed markedly with phytoplankton species (Fig. 2).

Pseudodiaptomus marinus egested (Fig. 2A) more than $8.95 \times 10^{6} \mathrm{um}^{3}$ copepod ${ }^{-1} \mathrm{~d}^{-1}$ in suspensions of Heterocapsa triquetra, Gymnodinium sanguineum, Prorocentrum triestinum, P. micans, Pyrophacus steinii and Eutreptiella sp. On the other hand, copepods fed with Gymnodinium nagasakiense, Gonyaulax spinifera, Protoceratium reticulatum, Olisthodiscus luteus, Fibrocapsa japonica and Pyramimonas aff. amylifera egested less than $2.68 \times 10^{6} \mu \mathrm{m}^{3}$ copepod $^{-1} \mathrm{~d}^{-1}$ The egestion rates were intermediate, ranging from $5.34 \times$ $10^{6}$ to $7.32 \times 10^{6} \mathrm{um}^{3}$ copepod ${ }^{-1} \mathrm{~d}^{-1}$, for copepods with Heterosigma akashiwo (NU), H. akashiwo (NIES-145), Chattonella marina and Pterosperma cristatum.

The egestion rates of Acartia omorii (Fig. 2B) were higher than $3.82 \times 10^{6} \mu^{3}$ copepod ${ }^{-1} \mathrm{~d}^{-1}$ when fed with Heterocapsa triquetra, Gymnodinium sanguineum, Gonyaulax spinifera, Prorocentrum triestinum, $P$. micans, Olisthodiscus luteus, Heterosigma akashiwo (NIES-145) and Eutreptiella sp. But less than $2.26 \times 10^{6}$ $\mu \mathrm{m}^{3}$ copepod ${ }^{-1} \mathrm{~d}^{-1}$ were egested by copepods in suspensions of the remaining flagellate species. There was almost no defecation (mean: 0.5 pellets copepod ${ }^{-1} \mathrm{~d}^{-1}$ ) in a suspension of Gymnodinium nagasakiense.

\section{Survival}

In filtered seawater, mortality of Pseudodiaptomus marinus was low during the first $8 d$, but this was followed by high mortality, and all individuals died by the 13th day (Fig. 3A). Median survival time was $9 \mathrm{~d}$. As shown in Fig. 3A, more than $66 \%$ of $P$. marinus survived to the end of the experiment in suspensions of Heterocapsa triquetra, Gymnodinium sanguineum, Gonyaulax spinifera, Protoceratium reticulatum, Prorocentrum triestinum, $P$. micans, Pyrophacus steinii, Heterosigma akashiwo (NU), H. akashiwo (NIES-145). Chattonella marina, Pterosperma cristatum, Pyramimonas aff. amylifera and Eutreptiella sp. High mortality (52 to $100 \%$ ) was observed for $P$. marinus fed with Gymnodinium nagasakiense, Fibrocapsa japonica and Olisthodiscus luteus with median survival times of 20 , 15 and $11 \mathrm{~d}$, respectively. In an experimental suspen-
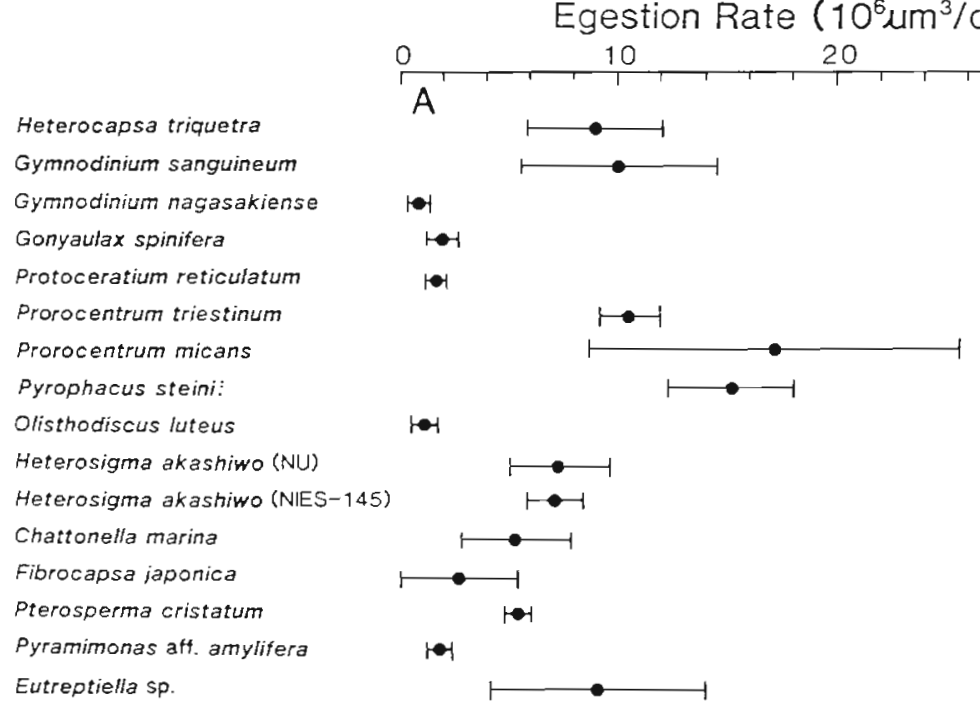

Fig. 2. (A) Pseudodiaptomus marinus and (B) Acartia omorii. Egestion rates of adult females fed on various red-tide flagellate species. Bars indicate standard deviation of the mean 


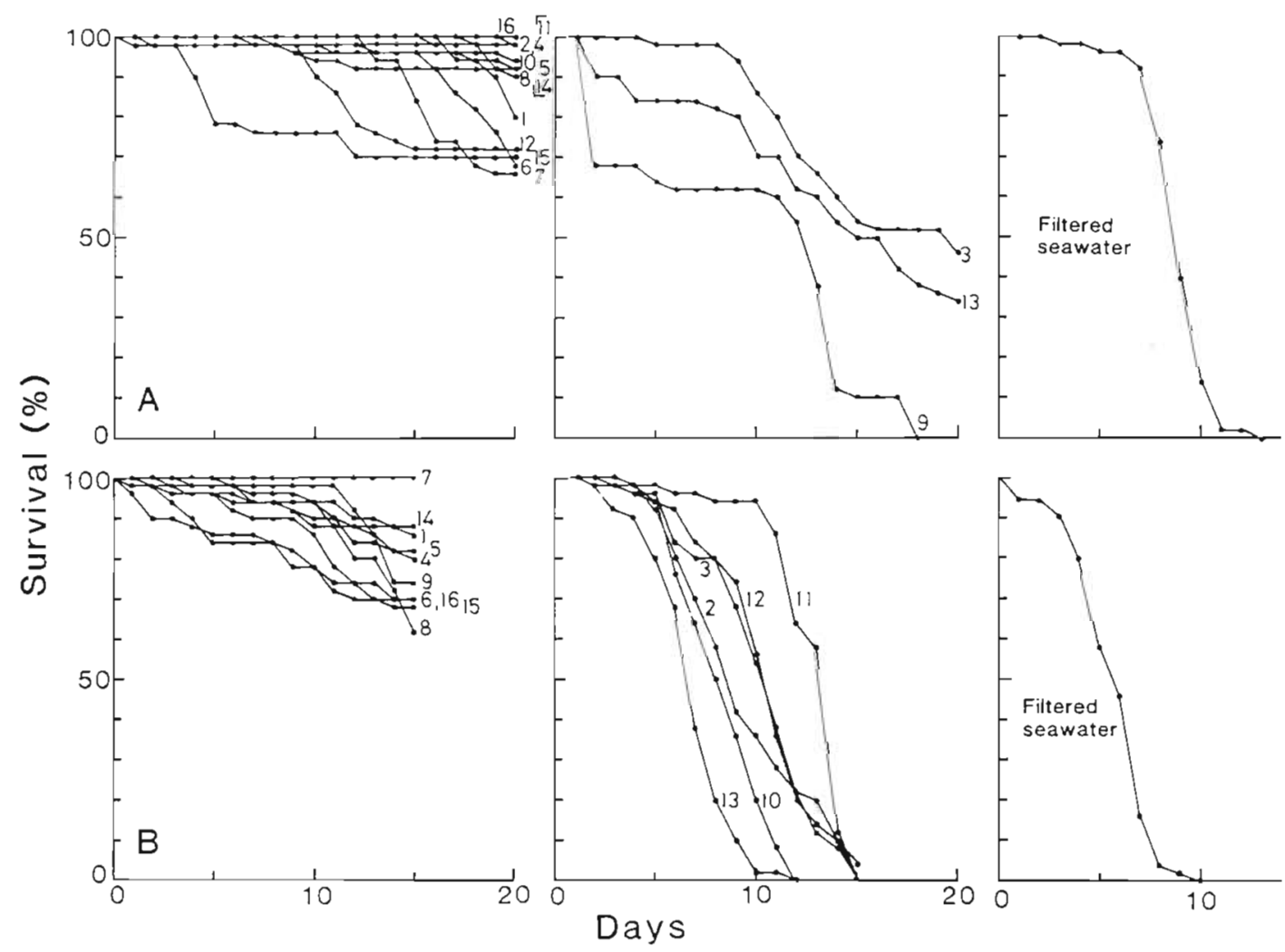

Fig. 3. (A) Pseudodiaptomus marinus and (B) Acartia omorii. Survival curves of adult females fed on various red-tide flagellate species. (1) Heterocapsa triquetra, (2) Gymnodinium sanguineum, (3) Gymnodinium nagasakiense, (4) Gonyaulax spinifera, (5) Protoceratium reticulatum, (6) Prorocentrum triestinum, (7) Prorocentrum micans, (8) Pyrophacus steinii, (9) Olisthodiscus luteus, (10) Heterosigma akashiwo, NU, (11) Heterosigma akashiwo, NIES-145, (12) Chattonella marina, (13) Fibrocapsa japonica, (14) Pterosperma cristatum. (15) Pyramimonas aff. amylifera, and (16) Eutreptiella sp.

sion of 0 . luteus, $32 \%$ died on the 2 nd day (Fig. 3A), a much higher mortality than that in filtered seawater.

Acartia omorii could survive up to $10 \mathrm{~d}$ under starved conditions (Fig. 3B) with a median survival time of $6 \mathrm{~d}$. Mortality was relatively low (0 to $38 \%$ ) when given Heterocapsa triquetra, Gonyaulax spinifera, Protoceratium reticulatum, Prorocentrum triestinum, $P$. micans, Pyrophacus steinii, Olisthodiscus luteus, Pterosperma cristatum, Pryramimonas aff. amylifera and Eutreptiella sp. (Fig. 3B). However, almost all individuals died by the end of the experiments with Gymnodinium nagasakiense, $G$. sanguineum, Heterosigma akashiwo (NU), H. akashiwo (NIES-145), Chattonella marina and Fibrocapsa japonica with median survival times of 9, 11, 8, 14, 11 and 7 d, respectively (Fig. 3B).

\section{Egg production}

As shown in Fig. 4, $100 \%$ of Pseudodiaptomus marinus produced a new egg sac, containing more than 20 eggs, 3 to $6 \mathrm{~d}$ after being fed with Heterocapsa triquetra, Gymnodinium sanguineum, Gonyaulax spinifera, Protoceratium reticulatum, Prorocentrum triestinum, P. micans, Pterosperma cristatum, Pyramimonas aff, amylifera and Eutreptiella sp. Although Gymnodinium nagasakiense and Fibrocapsa japonica supported egg production for 90 and $80 \%$ of females, respectively, their newly produced egg sac was much smaller, containing ca 10 eggs. Similarly, a small egg sac was produced by 20 to $50 \%$ of $P$. marinus fed with

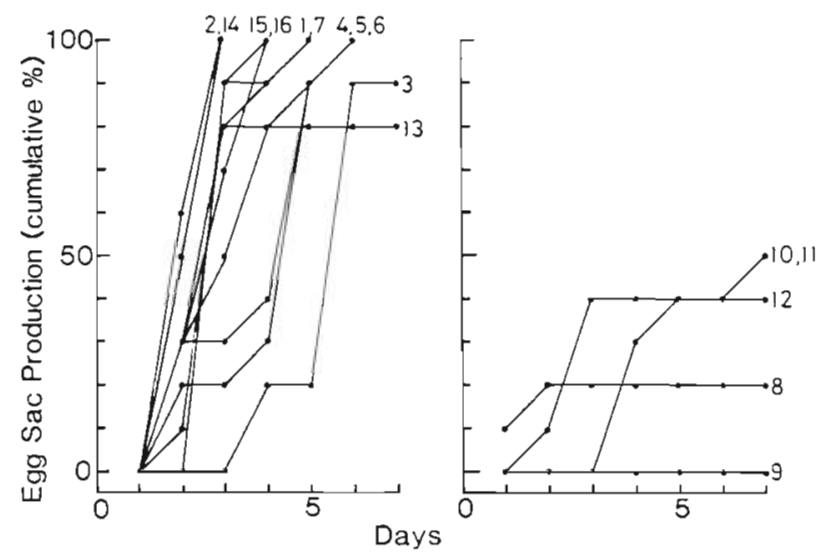

Fig. 4. Pseudodiaptomus marinus. Cumulative percentage of females carrying an egg sac, when fed on various red-tide flagellate species (see Fig. 3 for species name) 


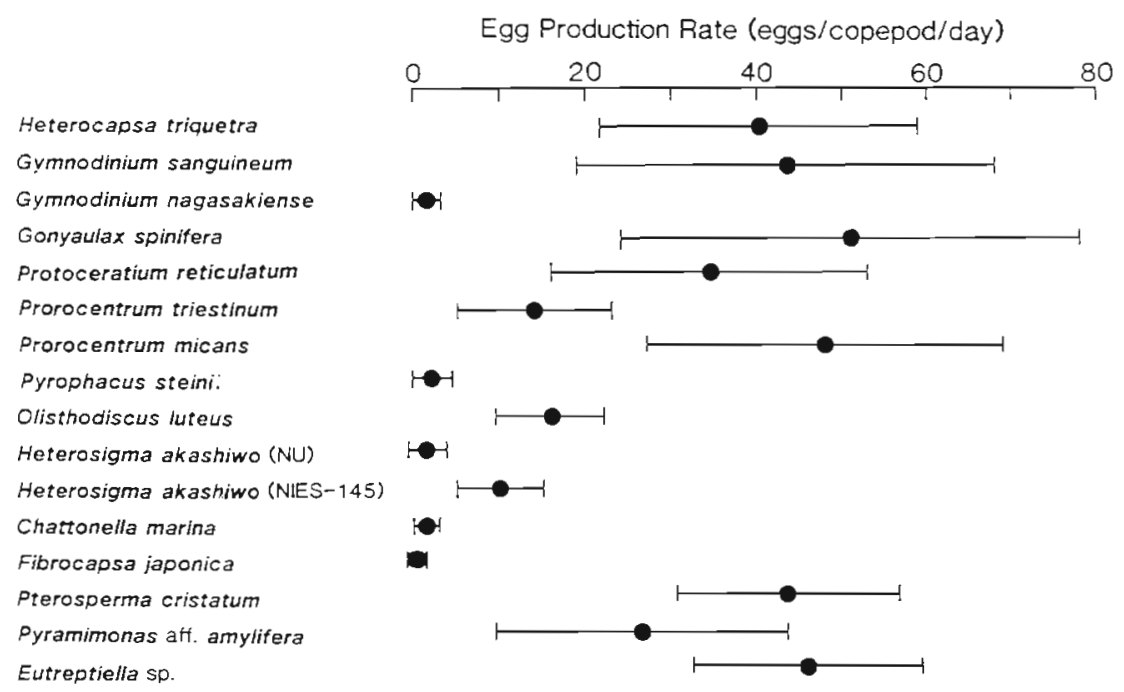

Fig. 5. Acartia omorii. Egg production rates when fed on various red-tide flagellate species. Bars indicate standard deviation of the mean

Pyrophacus steinii, Chattonella marina, Heterosigma akashiwo (NU), and $H$. akashiwo (NIES-145) (Fig. 4). No eggs were produced by $P$. marinus in a suspension of Olisthodiscus luteus (Fig. 4).

Acartia omorii showed relatively high egg production rates, 26.5 to 51.2 eggs copepod ${ }^{-1} \mathrm{~d}^{-1}$, when given Heterocapsa triquetra, Gymnodinium sanguineum, Gonyaulax spinifera, Protoceratium reticulatum, Prorocentrum micans, Pterosperma cristatum, Pyramimonas aff. amylifera and Eutreptiella sp. (Fig. 5). On the other hand, egg production rates were extremely low, 0.4 to 1.7 eggs copepod $\mathrm{d}^{-1} \mathrm{~d}^{-1}$, for copepods with
Gymnodinium nagasakiense, Pryrophacus steinii, Heterosigma akashiwo (NU), Chattonella marina and Fibrocapsa japonica (Fig. 5). Prorocentrum triestinum, Olisthodiscus luteus and $H$. akashiwo (NIES-145) supported intermediate rates of egg production, 10.1 to 15.9 eggs copepod ${ }^{-1} \mathrm{~d}^{-1}$ (Fig. 5).

\section{Evaluation of food quality}

Table 2 summarizes results of experiments to evaluate the food quality of phytoplankton species for

Table 2. Evaluation of food quality ( + : good, $-:$ bad, \pm : intermediate) of each flagellate species for Pseudodiaptomus marinus (P.m.) and Acartia omorii (A.o.) based on the results of egestion, survival and egg production rates

\begin{tabular}{|c|c|c|c|c|c|c|}
\hline \multirow[t]{2}{*}{ Species } & \multicolumn{2}{|c|}{ Egestion } & \multicolumn{2}{|c|}{ Survival } & \multicolumn{2}{|c|}{ Egg production } \\
\hline & P.m. & A.o. & P.m. & A.o. & P.m. & A.o. \\
\hline \multicolumn{7}{|l|}{ Dinophyceae } \\
\hline Heterocapsa triquetra & + & + & + & + & + & + \\
\hline Gymnodinium sanguineum & + & + & + & - & + & + \\
\hline Gymnodinium nagasakiense & - & - & \pm & - & \pm & - \\
\hline Gonyaulax spinifera & - & + & + & + & + & + \\
\hline Protoceratium reticulatum & - & - & + & + & + & + \\
\hline Prorocentrum triestinum & + & + & + & + & + & \pm \\
\hline Prorocentrum micans & + & + & + & + & + & + \\
\hline Pyrophacus steinii & + & \pm & + & + & \pm & - \\
\hline \multicolumn{7}{|l|}{ Raphidophyceae } \\
\hline Olisthodiscus luteus & - & + & - & + & - & \pm \\
\hline Heterosigma akashiwo (NU) & \pm & - & + & \pm & \pm & - \\
\hline Heterosigma akashiwo (NIES-145) & \pm & + & + & - & \pm & \pm \\
\hline Chattonella marina & \pm & - & + & - & \pm & - \\
\hline Fibrocapsa japonica & - & - & \pm & - & \pm & - \\
\hline \multicolumn{7}{|l|}{ Prasinophyceae } \\
\hline Pterosperma custatum & \pm & - & + & + & + & + \\
\hline Pyramimonas aff amilifera & - & \pm & + & + & + & + \\
\hline \multicolumn{7}{|l|}{ Euglenophyceae } \\
\hline Eutreptiella sp. & + & + & + & + & + & + \\
\hline
\end{tabular}


Pseudodiaptomus marinus and Acartia omorii. We simply judged 'good', 'intermediate' and 'poor' quality arbitrarily based on the results of each experiment.

We concluded that half the flagellates examined were of 'good' quality, i.e. Heterocapsa triquetra, Gonyaulax spinifera, Protoceratium reticulatum, Prorocentrum triestinum, $P$. micans, Pterosperma cristatum, Pyraminomas aff. amylifera and Eutreptiella sp. Although egestion rates were not always high, these species supported high survival and egg production rates in both copepod species. Gymnodinium sanguineum and Pyrophacus steinii were 'good quality' food for Pseudodiaptomus marinus, but for Acartia omorii, the former did not support high survival rates and the latter did not provide high egg production rates. The remaining phytoplankton species were evaluated as more or less 'poor quality' food. Remarkably poor results, i.e. extremely low egestion, survival and egg production rates, were observed for Olisthodiscus luteus fed to P. marinus, and for Gymnodinium nagasakiense, Heterosigma akashiwo (NU), Chattonella marina and Fibrocapsa japonica fed to $A$. omorii.

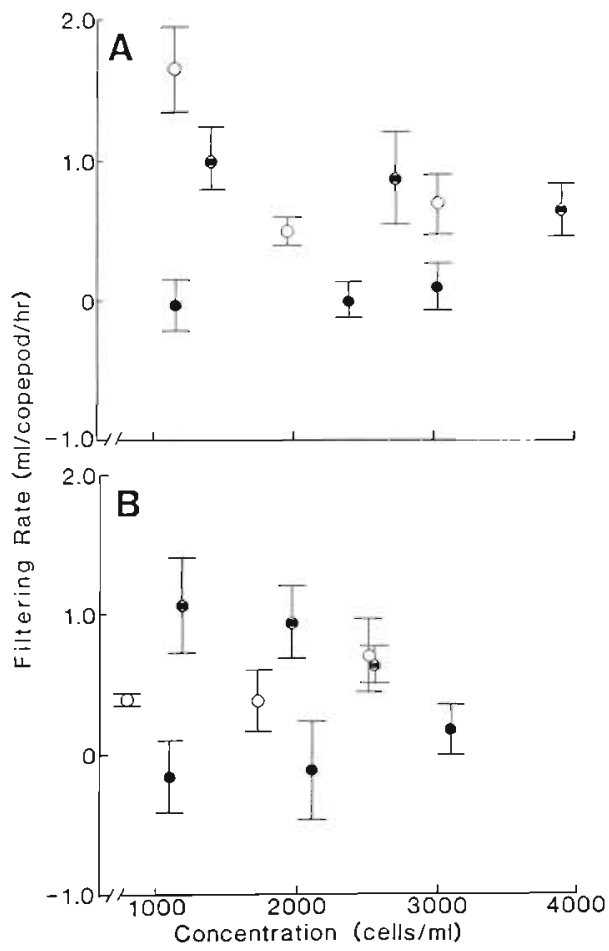

Fig. 6. (A) Pseudodiaptomus marinus and (B) Acartia omorii. Filtering rates of adult females on Heterocapsa triquetra. (o) Control cells (Heterocapsa triquetra) only; (e) control cells + filtrate of Olisthodiscus luteus culture (A) or Gymnodinium nagasakiensa culture $(B) ;(\bullet)$ control cells + filtrate of the homogenate of Olisthodiscus luteus cells (A) or Gymnodinium nagasakiense cells (B). Bars indicate standard deviation of the mean
The differences in food quality are probably related to differences in nutritional chemical compounds (e.g. carbon, nitrogen, protein, lipid) at least for those species which were ingested (evidenced by fecal pellet production). It was apparent, for most species judged as 'poor quality' that non-feeding was a reason for the high mortality and low egg production rates of copepods. However, this non-feeding behavior could not be explained by differences in shape, cell size or hardness of cell walls. Hence, we suspected some chemical compounds were involved, as was reported by Huntley et al. (1986) and Van Alstyne (1986). In the subsequent grazing experiments, responses of Pseudodiaptomus marinus to Olisthodiscus luteus and of Acartia omorii to Gymnodinium nagasakiense were investigated in detail.

\section{Occurrence of inhibitory compounds: intra- or extracellular?}

Filtering rates of Pseudodiaptomus marinus on Heterocapsa triquetra, a normally edible species, were determined at 3 different cell concentrations in 3 different treatments: $H$. triquetra was suspended in (1) filtered seawater, (2) filtered seawater containing filtrate of Olisthodiscus luteus culture, and (3) filtered seawater containing filtrate from the homogenate of $O$. Iuteus cells (Fig. 6A). Although P. marinus filtered at relatively high rates in Treatments (1) and (2) (overall means 0.95 and $0.85 \mathrm{ml}$ copepod ${ }^{-1} \mathrm{~h}^{-1}$ respectively), the copepods did not filter appreciably $(0.02 \mathrm{ml}$ copepod ${ }^{-1} \mathrm{~h}^{-1}$ ) in Treatment (3). At concentrations of 1156 to 1412 cells $\mathrm{ml}^{-1}$, the mean filtering rate $(1.65$ $\mathrm{ml}$ copepod $^{-1} \mathrm{~h}^{-1}$ ) in Treatment (1) was significantly ( $t$-test, $\mathrm{p}<0.05$ ) higher than the mean filtering rate (1.03 ml copepod $\left.\mathrm{m}^{-1} \mathrm{~h}^{-1}\right)$ in Treatment (2), which was in turn significantly $(p<0.01)$ higher than the mean value $\left(0.035 \mathrm{ml}\right.$ copepod $\left.^{-1} \mathrm{~h}^{-1}\right)$ in Treatment (3). Although, at concentrations of 2737 to 3037 cells ml $^{-1}$, there was no significant difference in mean filtering rates between Treatments (1) and (2) $(0.69$ and $0.88 \mathrm{ml}$ copepod ${ }^{-1} h^{-1}$, respectively), these values were significantly $(\mathrm{p}<0.01)$ higher than the filtering rate $(0.1$ $\mathrm{ml}$ copepod $^{-1} \mathrm{~h}^{-1}$ ) in Treatment (3). From these results, it was concluded that the filtrate of $O$. luteus culture did not inhibit feeding of $P$. marinus on $H$. triquetra, but the filtrate from the cell homogenate did inhibit feeding, indicating the inhibitory compounds were present intracellularly.

Fig. 6B shows the filtering rates of Acartia omorii in each treatment: Heterocapsa triquetra was suspended in (1) filtered seawater, (2) filtered seawater containing filtrate of Gymnodinium nagasakiense culture, and (3) filtered seawater containing filtrate from the homo- 
genate of $G$. nagasakiense cells. Overall means were $0.49,0.88$ and $-0.03 \mathrm{ml}$ copepod ${ }^{-1} \mathrm{~h}^{-1}$, respectively. At concentrations of 795 to 1196 and 1730 to 2107 cells $\mathrm{ml}^{-1}$, the mean filtering rates $(1.07$ and $0.94 \mathrm{ml}$ copepod $^{-1} h^{-1}$, respectively) in Treatment (2) were significantly $(p<0.05)$ higher than the mean rates $(0.39$

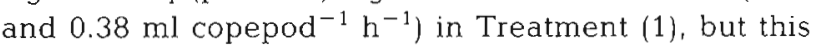
difference was not significant at concentrations of 2517 to 2556 cells $\mathrm{ml}^{-1}$. At concentrations of 795 to 1196 cells $\mathrm{ml}^{-1}$, the mean filtering rate $\left(-0.16 \mathrm{ml}\right.$ copepod $\left.{ }^{-1} \mathrm{~h}^{-1}\right)$ in Treatment (3) was significantly $(p<0.05)$ lower than the mean rate in Treatment (1), but at 1730 to 2107 cells $\mathrm{ml}^{-1}$, this difference (mean in Treatment [3]: $-0.11 \mathrm{ml}$ copepod $^{-1} \mathrm{~h}^{-1}$ ) was not significant. These results indicate the addition of homogenate filtrate of $G$. nagasakiense cells may reduce the filtering rate of $A$. omorii, but the addition of culture filtrate may increase the filtering rate. Hence, it was concluded the inhibitory compounds were also present within $G$ nagasakiense cells.

\section{Physico-chemical properties of inhibitory compounds}

Fig. 7 shows the effect of heated filtrate from Olisthodiscus luteus cell homogenate on the filtering rate of Pseudodiaptomus marinus on Heterocapsa triquetra. Filtering rate tended to increase with the

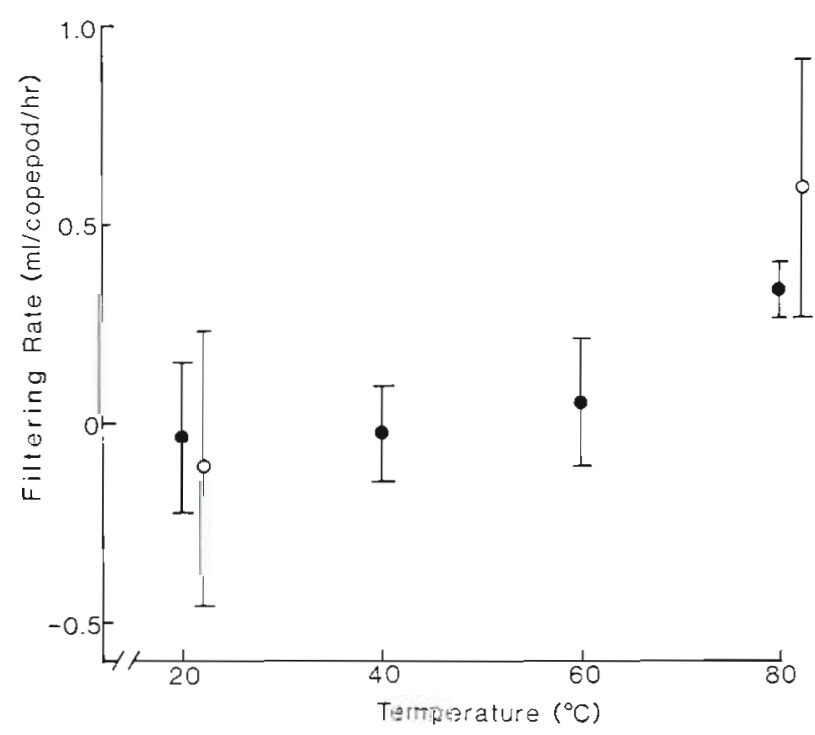

Fig. 7. Pseudodiaptomus marinus and Acartia omorii. Effect of heated filtrate from the homogenate of Olisthodicus luteus or Gymnodinium nagasakiense on filtering rate of copepods on Heterocapsa triquetra. (•) Filtering rate of adult female $P$. marinus; $\Leftrightarrow$ filtering rate of adult female $A$. omorij. Bars indicate standard deviation of the mean temperature at which the cell homogenate was treated. However, the mean filtering rate even in experimental suspension with $80^{\circ} \mathrm{C}$-heated filtrate $\left(0.33 \mathrm{ml}\right.$ copepod $\left.{ }^{-1} \mathrm{~h}^{-1}\right)$ was not significantly different from that in control suspension (treated at $20^{\circ} \mathrm{C}$, $0.01 \mathrm{ml} \mathrm{copepod}^{-1} \mathrm{~h}^{-1}$ ).

Similarly the filtering rate of Acartia omorii increased to $0.59 \mathrm{ml}$ copepod ${ }^{-1} \mathrm{~h}^{-1}$ in experimental suspension with Gymnodinium nagasakiense cell homogenate heated to $80^{\circ} \mathrm{C}$ (Fig. 7). However, this was again not significantly different from the mean filtering rate in control suspension $\left(-0.11 \mathrm{ml} \mathrm{copepod}^{-1} \mathrm{~h}^{-1}\right)$.

Fig. 8 shows the effect of aged filtrate from Olisthodiscus luteus cell homogenate on the filtering rate of Pseudodiaptomus marinus. There was a clear tendency for filtering rate to increase as the filtrate became older. Mean filtering rates in experimental suspension with 2 to $6 \mathrm{~h}$ old filtrate $\left(0.01\right.$ to $0.27 \mathrm{ml}$ copepod $\left.^{-1} \mathrm{~h}^{-1}\right)$ were not different from the filtering rate in control suspension, which contained $0 \mathrm{~h}$ old filtrate $10.01 \mathrm{ml}$ copepod $\left.{ }^{-1} \mathrm{~h}^{-1}\right)$. Mean filtering rates with 12 and $24 \mathrm{~h}$ old filtrate $\left(0.63,0.84 \mathrm{ml} \mathrm{copepod}^{-1} \mathrm{~h}^{-1}\right.$, respectively) were significantly $(p<0.05)$ higher than the mean value in control suspension.

Acartia omorii filtered at significantly higher rates in experimental suspension with $12 \mathrm{~h}$ old $(0.53 \mathrm{ml}$ copepod $\left.{ }^{-1} \mathrm{~h}^{-1}\right)$ and $24 \mathrm{~h}$ old $\left(0.52 \mathrm{ml}\right.$ copepod $\left.{ }^{-1} \mathrm{~h}^{-1}\right)$ filtrate from Gymnodinium nagasakiense cell homogenate than in control suspension (Fig. 8). These results indicate that the inhibitory compounds produced by both Olisthodiscus luteus and $G$. nagasakiense were labile.

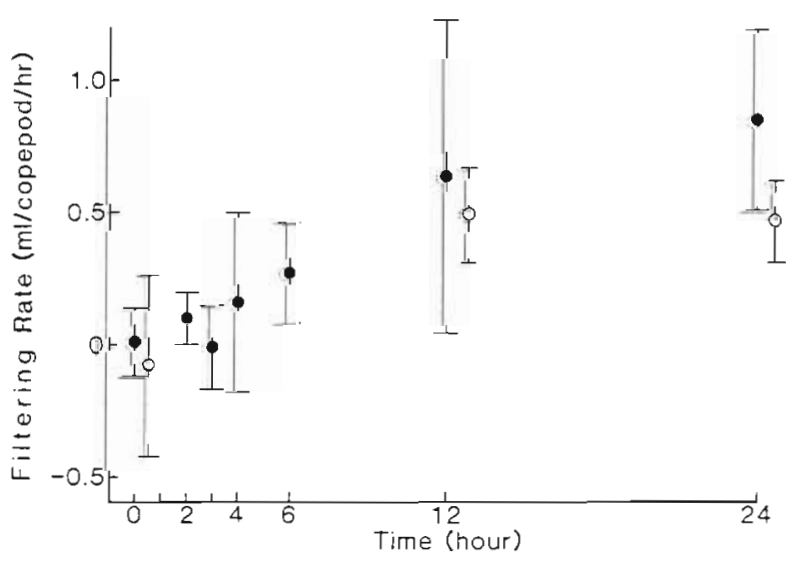

Fig. 8. Pseudodiaptomus marinus and Acartia omorii. Effect of aged filtrate from the homogenate of Olisthodicus luteus or Gymnodinium nagasakiense on filtenng rate of copepods on Heterocapsa triquetra. (-) Filtering rate of adult female $P$. marinus $(0$ filtering rate of adult female $A$ omorii. Bars indicate standard deviation of the mean 


\section{DISCUSSION}

Since Pseudodiaptomus marinus and Acartia omorii, the latter being much more abundant than the former (Uye et al. 1983, Ueda 1986, 1987), occur in inlet waters of Japan, where red tides often take place, both copepods are likely to encounter blooms of various phytoplankton species including the 15 flagellates used in the present study. Since these flagellates are of preferred cell size for adult female copepods, they should be ingested and assimilated, unless they lack some nutritional requirements for copepods or have hard undigestible cell walls. Some flagellate species were readily eaten by copepods and supported high survival and egg production rates, but others were eaten at low rates or almost completely rejected. Among the latter, Olisthodiscus luteus was almost completely rejected by $P$. marinus, and Gymnodinium nagasakiense, Heterosigma akashiwo (NU), Chattonella marina and Fibrocapsa japonica were totally rejected by $A$. omorii. We found that the rejective feeding was due to the effect of deterrent chemical compounds in the intracellular product, and this was confirmed for 2 representative species, $O$. luteus and $G$. nagasakiense.

\section{Feeding interaction between flagellates and copepods}

The present study shows raphidophycean algae are, in general, undesirable food to copepods. However, the food value of these flagellates differed from one copepod species to another. For example, Olisthodiscus luteus was readily eaten by Acartia omorii, and Heterosigma akashiwo (NU), Chattonella marina and Fibrocapsa japonica were efficiently utilized by Pseudodiaptomus marinus (Table 2). Owing to the similar morphologies of $O$. luteus and $H$. akashiwo, the latter has often been misidentified as $O$. luteus (Hara et al. 1985, Hara \& Chihara 1987). O. Iuteus (it is likely to have been $H$. akashiwo) was reported as an unsatisfactory food for copepods (Tomas \& Deason 1981) and tinntinnids (Verity \& Stoecker 1982). Chotiyaputta \& Hirayama (1978) reported that $H$. akashiwo (NU) (the same strain as that used in the present experiment) was also an unsatisfactory food for a rotifer, Brachionus plicatilis. Although $C$. marina was inferior food in the present study, Ito \& Imai (1986) and Uye (1986) reported Chattonella (antiqua and marina) were readily ingested by copepods. However, they did not examine whether Chattonella spp. were utilized by these copepods to support high survival and egg production rates.

Among 8 dinoflagellate species examined, only Gymnodinium nagasakiense was an unsatisfactory food for both copepod species. This was more marked for Acartia omorii than for Pseudodiaptomus marinus; the latter could to some extent utilize it for survival and egg production (Table 2). Gyrodinium aureolum, which is morphologically very similar and hence suspected as a synonym of $G$. nagasakiense (Tangen 1977, Partensky et al. 1988), was an inferior food for Calanus helgolandicus and Temora longicornis (Gill \& Harris 1987). Although Huntley et al. (1986) demonstrated Protoceratium reticulatum (subsequently referred to by its synonym, Gonyaulax grindleyi, by Sykes \& Huntley 1987 and Huntley et al. 1987) was rejected by Calanus pacificus and Paracalanus parvus, in our study this species supported high survival and egg production rates of both copepods in spite to low egestion rates. These results suggest food value (or rejection or nonrejection) of a given phytoplankton species may differ with strain or culture condition of phytoplankton, as well as with grazer species.

If many herbivores respond similarly to Pseudodiaptomus marinus and Acartia omorii in these experiments, then reduction of their feeding pressure may be a significant factor in the development of flagellate populations to red tide conditions. Avoidance of a bloom area by zooplankton (Fiedler 1982) may also favor red-tide formation. When monospecific blooms of these flagellates occur over a wide area, our results suggest disastrous effects to herbivore populations. Under such conditions, they could not acquire the energy to meet minimum requirements for respiration and metabolism. Then a significant number of grazers would disappear from the bloom area, further contributing to maintenance of the bloom. Such deleterious conditions for copepods may be alleviated if a considerable amount of good quality phytoplankers coexist.

In contrast, most dinoflagellate species (but see exceptionally low results for Gymnodinium sanquineum and Pyrophacus steinii with Acartia omorii; Table 2), prasinophytes and a euglenophyte used in the present experiments were satisfactory food to copepods and no harmful effects were found even under bloom concentrations. Hence, the development and persistence of blooms of these species are expected to be influenced by grazing pressure of zooplankton.

\section{Production of inhibitory chemical compounds}

A variety of dissolved organic compounds are produced by phytoplankton (Fogg 1966). These compounds surrounding cells may be detected by copepods through chemoreceptors to enable selection of food particles (Koel \& Strickler 1981, Andrews 1983, Poulet et al. 1986). In particular, free amino acids are important feeding stimuli (Poulet \& Marsot 1980, Poulet \& Quellet 1982, Gill $\&$ Poulet 1988 ). On the other hand, some phytoplankton 
species produce metabolites which are deterrent or toxic toward phytoplankton (i.e. allelopathy; cf. Pratt 1966, Lewis 1986), zooplankton (Huntley et al. 1986) or fish (White 1980,1981 ). The production of toxic compounds, especially toward zooplankton, is considered a chemical defense against grazers. However, except for a report by Abe \& Hirayama (1979), who found a lethal effect of Gymnodinium nagasakiense on a rotifer (Brachionus plicatilis), production of toxins causing acute mortality of grazers has not to our knowledge been demonstrated in marine phytoplankton.

In the present study, 5 (1 dinoflagellate and 4 raphidophytes) out of 15 flagellate species were presumed to produce compounds which deter feeding by copepods. These compounds, however, did not cause acute mortality of copepods. Since 2 flagellates, Olisthodiscus luteus and Gymnodinium nagasakiense, were found to contain the inhibitory compounds within their cells, their toxic chemical properties may not be detected by copepods before ingestion, but can be detected after the cells are ingested and broken. However, Huntley et al. (1986) found that compounds which inhibited feeding of Calanus pacificus were derived from the extracellular products of Protoceratium reticulatum. In addition, Van Alstyne (1986) reported that feeding of Centropages hamatus was inhibited by both intra- and extracellular products of $O$. luteus and intracellular compounds of Scrippsiella trochoidea. Sykes \& Huntley (1987) observed, through a video system, the behavior of $C$. pacificus presented with $P$. reticulatum and found the copepods actually ingested the cells but $40 \%$ of the copepods regurgitated after 45 to $120 \mathrm{~min}$. These findings suggest that chemical properties of extracellular products might not be successfully detected by copepods before cells are ingested.

Responses to cell exudates (smell) are more ecologically relevant than responses to cell extracts (taste), because copepods would not necessarily have to kill cells to detect their chemical properties. As demonstrated by Huntley et al. (1986) for Protoceratium reticulatum, the active compounds derived from Olisthodiscus luteus and Gymnodinium nagasakiense were also ephemeral, being deactivated within $12 \mathrm{~h}$ at $20^{\circ} \mathrm{C}$. The importance of plant defensive mechanisms, especially the role of secondary metabolites as chemical defenses against herbivores, has been recognized (Whittaker \& Feeny 1971). It has been argued that the evolution of defense mechanisms in terrestrial plants may be responsive to the plant's cost/benefit relationships. In this sense, production of defensive chemical compounds is costly for phytoplankton. This was explicitly examined by Huntley et al. (1986) who found growth rates of dinoflagellates exuding toxic compounds were significantly lower than those which do not contain such compounds. If ephemeral bioactive compounds reside extracellularly, the production of such compounds is energetically expensive because they must be continuously produced and released. If the compounds reside intracellularly, their production is energetically more economical, although individual cells are exposed to the risk of being killed by grazers in this case. We speculate grazers are capable of discriminating toxic cells through trial-and-error experiences in ingesting bad-tasting species, although such a learning effect has not been explicitly demonstrated in marine zooplankton. Ingested cells are a sacrifice for the remaining population. Being bad-tasting is then a selective advantage for the population, but not for a single cell.

Acknowledgements. We are grateful to Dr R. P. Harris of Plymouth Marine Laboratory for his interest and critical reading of the manuscript. We also thank Dr T. Onbe for comments and discussion during preparation of the manuscript. Gratitude is extended to Drs K. Hirayama and S. Iizuka of Nagasaki University and Dr M. M. Watanabe of the National Institute for Environmental Studies for providing phytoplankton cultures. This research was supported partially by a grant from the Ministry of Education, Science and Culture, Project No. 63480070

\section{LITERATURE CITED}

Abe, T., Hirayama, K. (1979). Lethal effect of Gymnodinium $\mathrm{sp}$. on the rotifer, Brachionus plicatilis. Bull. Fac. Fish. Nagasaki Univ. 46: 1-6 (in Japanese, English abstract)

Alcaraz, M., Paffenhöfer, G.-A., Strickler, J. R. (1980). Catching the algae: a first account of visual observations on filter-feeding calanoids. In: Kerfoot, W. C. (ed.) Evolution and ecology of zooplankton communities. University Press of New England, Hanover, p. 241-248

Andrews, J. C. (1983). Deformation of the active space in the low Reynolds number feeding current of calanoid copepods. Can. J. Fish. Aquat. Sci. 40: 1293-1302

Boyd, C. (1976). Selection of particle sizes by filter-feeding copepods: a plea for reason. Limnol. Oceanogr. 21: 175-180

Chotiyaputta, C., Hirayama, K. (1978). Food selectivity of the rotifer Brachionus plicatilis feeding on phytoplankton. Mar. Biol. 45: 105-111

Donaghay, P., Small, L. F. (1979). Food selection capabilities of the estuarine copepod Acartia clausi Mar. Biol. 52: $137-146$

Fiedler, P. (1982). Zooplankton avoidance and reduced grazing responses to Gymnodinium splendens (Dinophyceae). Limnol. Oceanogr 27: 961-965

Fogg, G. E. (1966). The extracellular products of algae. Oceanogr. mar. Biol. A. Rev. 4: 195-212

Friedman, M. M., Strickler, J. R. (1975). Chemoreception and feeding in the calanoid copepods. Proc. natn. Acad. Sci. USA. $72: 4185-4188$

Frost, B. W (1972). Effects of size and concentration of food particles on the feeding behavior of the marine planktonic copepod Calanus pacificus. Limnol Oceanogr. 17. $805-815$

Frost, B. W. (1977). Feeding behavior of Calanus pacificus in mixtures of food particles. Limnol. Oceanogr. 22: 472-491

Frost, B. W. (1980). Grazing. In: Morris, I. (ed.) The physiological ecology of phytoplankton. Blackwell, Oxford, p. $465-491$

Gill, C. W., Harris, R. P. (1987). Behavioural responses of the 
copepods Calanus helgolandicus and Temora longicornis to dinoflagellate diets. J. mar biol. Ass. U.K. 67: 785-801

Gill, C. W., Poulet, S. A. (1988). Responses of copepods to dissolved free amino acids. Mar Ecol. Prog. Ser. 43: $269-276$

Guillard, R. R. L., Ryther, J. H. (1962). Studies on marine planktonic diatoms. I. Cyclotella nana Hustedt and Detonula confervacea (Cleve) Gran. Can. J. Microbiol. 5 229-239

Hara, Y., Chihara, M. (1987). Morphology, ultrastructure and taxonomy of the raphidophycean alga Heterosigma akashiwo. Bot. Mag., Tokyo 100: 151-163

Hara, Y., Inouye, 1., Chihara, M. (1985). Morphology and ultrastructure of Olisthodiscus luteus (Raphidophyceae) with special reference to the taxonomy. Bot. Mag., Tokyo 98: 251-262

Huntley, M. E. (1982). Yellow water in La Jolla Bay, California, July 1980. II. Suppression of zooplankton grazing. J. exp. mar. Biol. Ecol. 63: 81-91

Huntley, M. E., Sykes, P., Rohan, S., Marin, V. (1986). Chemically-mediated rejection of dinoflagellate prey by the copepods Calanus pacificus and Paracalanus parvus mechanism, occurrence and significance. Mar. Ecol. Prog Ser 28: 105-120

Huntley, M. E., Ciminiello, P., Lopez, M. D. G. (1987). Importance of food quality in determining development and survival of Calanus pacificus (Copepoda: Calanoida). Mar Biol. 95: 103-113

Ito, K., Imai, 1. (1986). Grazing on Chattonella marina and production of fecal pellets by copepods. Bull. Nansei Reg Fish. Res. Lab. 20: 115-126

Ives, J. D. (1987). Possible mechanisms underlying copepod grazing responses to levels of toxicity in red tide dinoflagellates. J. exp mar Biol. Ecol. 112: 131-145

Koehl, M. Strickler, J. R. (1981). Copepod feeding currents: food capture at low Reynolds number Limnol. Oceanogr 26: $1062-1073$

Lewis, W. M. (1986). Evolutionary interpretations of allelochemical interactions in phytoplankton algae. Am. Nat. 127: 184-194

Mullin, M. M., Sloan, P. R., Eppley, P. W (1966). Relationship between carbon content, cell volume and area in phytoplankton. Limnol. Oceanogr. 11: 307-311

Nishio, S. (1982). Ichthyotoxicity. In: Okaichi et al. (eds.) Toxic phytoplankton: occurrence, mode of action, and toxins. Kosaisha-Koseikaku, Tokyo, p. 50-61 (in Japanese)

Nival, P., Nival, S. (1976). Particle retention efficiencies of a herbivorous copepod, Acartia clauis (adult and copepodite stages): effects of grazing. Limnol. Oceanogr. 21: 24-38

Okaichi, T (1987). Science of red tides. Koseisha-Koseikaku, Tokyo (in Japanese)

Partensky, F., Vanlot, D., Coute, A., Sournia, A. (1988). Morphological and nuclear analysis of the bloom-forming dinoflagellates Gyrodinium of. aureolum and Gymnodinium nagasakiense. J. Phycol. 24: 408-415

Poulet, S. A., Marsot, P. (1978). Chemosensory grazing by marine calanoid copepods (Arthoropoda: Crustacea). Science 200: 1403-1405

Poulet, S. A., Marsot, P. (1980). Chemosensory feeding and food-gathering by omnivorous marine copepods. In: Kerfoot, W. C. (ed.) Evolution and ecology of zooplankton communities. University Press of New England, Hanover, p. $198-218$

Poulet, S. A., Quellet, G. (1982). The role of amino acids in the chemosensory swarming and feeding of marine copepods J. Plankton Res. 4: 341-361

Poulet, S. A., Samain, J. F., Moal, J. (1986). Chemoreception and food requirements among copepods. In: Schreiver, G. Schminke, H. K., Shih, C. T (eds.) Proceedings 2nd International Conference on Copepoda. Syllogeus No. 58, National Museum of Canada, Ottawa, p. 426-442

Pratt, D. M. (1966). Competition between Skeletonema costatum and Olisthodiscus luteus in Narragansett Bay. Limnol. Oceanogr. 11: 447-455

Richman, S., Heinle, D. H., Huff, R. (1977). Grazing by adult estuarine calanoid copepods of the Chesapeake Bay. Mar. Biol. 42: 69-84

Steele, J. H. (1974). The structure of marine ecosystems. Blackwell, Oxford

Sykes, P. F., Huntley, M. E. (1987). Acute physiological reac tions of Calanus pacificus to selected dinoflagellates: direct observations. Mar Biol. 94: 19-24

Tangen, K (1977). Blooms of Gyrodinium aureolum (Dinophyceae) in north European waters, accompanied by mortality in marine organisms. Sarsia 63: 123-133

Tomas, C. R. Deason, E. E. (1981). The influence of grazing by two Acartia species on Olisthodiscus luteus Carter. P. S. Z. N. I. Mar Ecol. 2: 215-223

Turner, J. T., Anderson, D. M. (1983). Zooplankton grazing during dinoflagellate blooms in a Cape Cod embayment. with observations of predation upon tintinnids by copepods. P. S. Z. N. I. Mar. Ecol. 4: 359-374

Ueda, H. (1986). Taxonomic reexamination and geographical distribution of copepods known as Acartia clausi in Japanese coastal and inlet waters. J. oceanogr Soc. Japan 42: 134-138 (in Japanese, English abstract)

Ueda, H. (1987). Temporal and spatial distribution of the two closely related Acartia species A. omorii and A. hudsonica (Copepoda, Calanoida) in a small inlet water of Japan. Estuar. cstl Shelf Sci. 24:691-700

Uye, S. (1986). Impact of copepod grazing on the red-tide flagellate Chattonella antiqua. Mar. Biol. 92: 35-43

Uye, S., Iwai, Y., Kasahara, S. (1983). Growth and production of the inshore marine copepod Pseudodiaptomus marinus in the central part of the Inland Sea of Japan. Mar. Biol. 73: 91-98

Uye, S., Kasahara, S. (1983). Grazing of various developmental stages of Pseudodiaptomus marinus (Copepoda: Calanoida) on naturally occurring particles. Bull. Plankton Soc. Japan 30: 147-158

Van Alstyne, K. L. (1986). Effects of phytoplankton taste and smell on feeding behavior of the copepod Centropages hamatus. Mar. Ecol. Prog. Ser 34: 187-190

Verity, P., Stoecker, D. (1982). Effects of Olisthodiscus luteus on the growth and abundance of tintinnids. Mar. Biol. 72: 79-87

Watras, C. J., Garcon, V C., Olson, R. J., Chisholm, S. W., Anderson, D. M. (1985). The effect of zooplankton grazing on estuarine blooms of the toxic dinoflagellate Gonyaulax tamarensis. J. Plankton Res. 7: 891-908

White, A. W. (1980). Recurrence of kills of Atlantic herring (Clupea harengas harengas) caused by dinoflagellate toxins transferred through herbivorous zooplankton. Can. J. Fish. Aquat. Sci. 37: 2262-2265

White, A. W. (1981). Marine zooplankton can accumulate and retain dinoflagellate toxin and cause fish kills. Limnol. Oceanogr 26: 103-109

Whittaker, R. H., Feeny, P. (1971). Allelochemics: chemical interactions between species. Science $171 \quad 757-770$

Manuscript first received: April 25, 1989

Revised version accepted: September 8, 1989 